\title{
Chemical composition of runoff water in Raipur city, central India
}

\author{
Balram Ambade
}

Received: 14 January 2014/ Accepted: 18 February 2014/Published online: 4 April 2014

(C) The Author(s) 2014. This article is published with open access at Springerlink.com

\begin{abstract}
Runoff water is an important transporting medium for various pollutants from land to surface water. Several mobiles and stationary sources such as vehicles, steel cement and thermal power plants, cooking, street, construction debris, etc. are emitting effluents in the environment of the central India. The rain runoff water washes out the air as well as land pollutants and flushes out into water bodies. Therefore, rain runoff water pollution in most urbanized and industrialized city of central India, i.e., Raipur during rainy season (May-September 2012) is analyzed statistically using cluster and principal component analysis to assess sources. The cluster analysis grouped runoff water samples into two clusters based on the similarity of runoff water quality characteristics of the total variance. The factor analysis differentiated the diffused sources of runoff water contaminants. The enrichment factors and runoff fluxes of the contaminants are discussed.
\end{abstract}

Keywords Runoff water quality - Cluster analysis . Factor analysis · Removal fluxes · Central India

\section{Introduction}

The major sources of runoff pollution are sewage overflows, road salt and grit, street and construction debris nutrient pollutants from livestock and fertilizer use pesticides, atmospheric fallout, deciduous leaf litter, etc. (Burton and Pitt 2000). The most common contaminants in runoff are heavy metals, inorganic salts, aromatic hydrocarbons, etc. Urban runoff water

B. Ambade ( $\square)$

Department of Chemistry, National Institute of Technology,

Jamshedpur 831014, India

e-mail: bambade.chem@nitjsr.ac.in pollution is one of the leading causes of water pollution and becomes worse with population growth and urbanization. Rain runoff volumes are enhanced in urban areas due to an increase in impervious surfaces, i.e., Streets, buildings, parking, etc. The runoff water pollution is one of the major diffuse pollution sources for depleting water qualities (Tosic et al. 2009). Surface waters (i.e., streams, rivers, ponds and lakes) are particularly vulnerable because they are directly exposed to contaminants released into the air and to direct discharges from point or non-point sources. Several studies have shown that a wide variety of pollutants are present in rainwater runoff, mainly resulting from the wash-off of the surface pollutants (Patel et al. 2010; Berndtsson et al. 2009; Chang et al. 2004; Göbel et al. 2007; Ha 2003; Hao et al. 2006; Mangani et al. 2005; Neal et al. 2004; Polkowska et al. 2001, 2002; Taebi and Droste 2004; Tsiouris et al. 2002) Significant level of metals in the runoff from urban areas, especially in highway runoff, has been reported (Allen et al. 2001; Heijerick et al. 2002; Nabizadeh et al. 2005; Nouri and Naghipour 2002; Revitt et al. 1990; Bouwman et al. 2002). The cities in India undergone a continual shift in population and development trends and these have tremendously affected the levels of urban runoff water (Hessen et al. 1997; Avvannavar and Shrihari 2008). The urban runoff water quality greatly affects the surface and groundwater quality, fishing, animal and bird life, agriculture production, etc. in India (Chattopadhyay et al. 2005; Mujumdar 2008; Rao and Mamatha 2004; Sargaonkar 2006; Solaraj et al. 2010; Patel et al. 2012; Venugopal et al. 2009; Zafar and Alappat 2005). Water pollution is a very serious problem in India, which is the second most populous nation in the world. It is estimated that over $\approx 70 \%$ of all of the India surface water is polluted in some way and many of the groundwater reserves have also been contaminated as a result of runoff pollutants.

Runoff indicates surface water runoff. Water that does not get absorbed into the soil, or rise back into the 


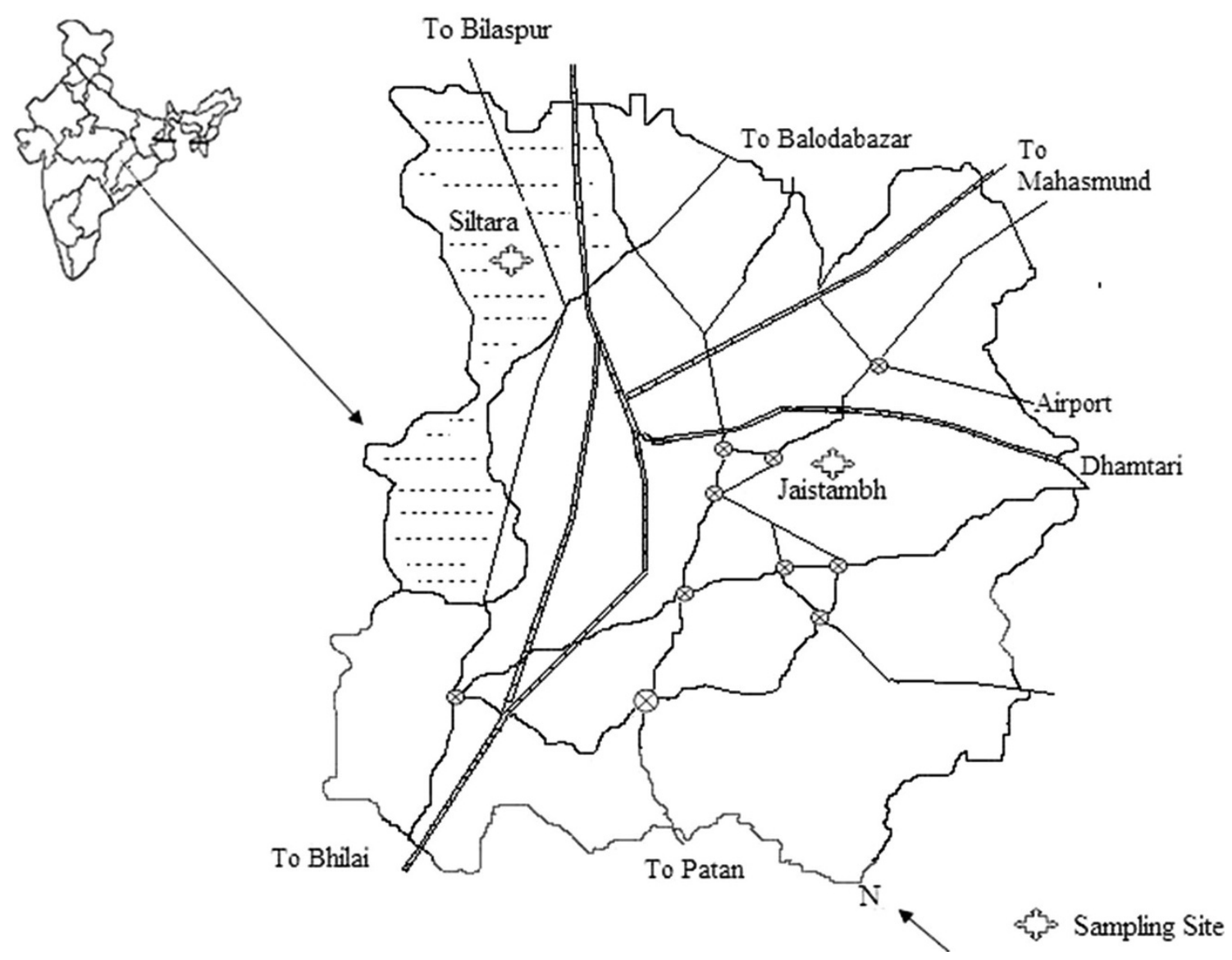

Fig. 1 Geographical representation of sampling point

atmosphere as water vapor, will run off surfaces collecting in varied locations. (In low-lying areas, on floodplains, etc.). The environment in which water from precipitation lands will determine the likelihood of surface runoff. For instance, paved areas prevent water from infiltrating into the ground. The water will run off the surface if evaporation does not take place. Urbanization increases surface runoff, by creating more impervious surfaces, such as pavement and buildings do not allow percolation of the water down through the soil to the aquifer. (Ambade 2012).

This study comprises the application of multivariate statistical techniques to identify water quality variables and possible sources of the runoff water quality parameters.

\section{Materials and methods}

Study area

Raipur $\left(21^{\circ} 24^{\prime} \mathrm{N}\right.$ and $\left.81^{\circ} 63^{\prime} \mathrm{E}\right)$ capital of Chhattisgarh state, central India was selected for the proposed studies due to the severe emission of pollutants from various sources
(Fig. 1). The city is spread over $\approx 1,000 \mathrm{~km}^{2}$ with $\approx 2$ million habitants. Several ferro-alloy, sponge iron and cement plants are in operation in this city and its surroundings. The total amount of rain water precipitated in Raipur during the year, June-September, 2012 was $\approx 67 \mathrm{~cm}$.

\section{Sample collection}

Fifteen rain runoff water samples were collected from the main commercial area (Jaitambh) and industrial area (Siltara) during months, June-September, 2012. A 5-1 cleaned polyethylene container was used for collection of the runoff water using prescribed methods (APHA 2005). After collection, the runoff water was filtered and physical parameters, i.e., $\mathrm{pH}$, conductivity and TDS values were measured. The sample was divided into two portions. The first portion was used for the analysis of anions and cations. The second portion was acidified with a few drops of ultrapure nitric acid (E. Merck) for analysis of the metals. The samples were kept airtight in 250-ml polyethylene bottles and refrigerated at the $4{ }^{\circ} \mathrm{C}$ for further analysis. 
Table 1 Physical parameters of runoff water in Raipur city

\begin{tabular}{lllllcc}
\hline $\begin{array}{l}\text { S. } \\
\text { no. }\end{array}$ & Site & Date & $\begin{array}{l}\text { Level } \\
(\mathrm{cm})\end{array}$ & $\mathrm{pH}$ & $\begin{array}{l}\text { Conductivity } \\
\left(\mu \mathrm{S} \mathrm{cm}^{-1}\right)\end{array}$ & $\begin{array}{l}\text { TDS } \\
\left(\mathrm{mg} \mathrm{l}^{-1}\right)\end{array}$ \\
\hline 1 & UC & $07 / 06 / 2012$ & 03 & 6.32 & 902 & 451 \\
2 & UC & $12 / 06 / 2012$ & 14 & 7.10 & 862 & 431 \\
3 & UC & $23 / 06 / 2012$ & 08 & 6.27 & 790 & 395 \\
4 & UC & $27 / 06 / 2012$ & 53 & 7.23 & 917 & 472 \\
5 & UC & $28 / 06 / 2012$ & 47 & 7.44 & 1,008 & 550 \\
6 & UC & $29 / 06 / 2012$ & 48 & 6.91 & 1,893 & 1,009 \\
7 & UC & $10 / 07 / 2012$ & 25 & 7.82 & 809 & 405 \\
8 & UC & $22 / 08 / 2012$ & 29 & 6.20 & 659 & 554 \\
9 & UC & $25 / 08 / 2012$ & 06 & 6.49 & 859 & 436 \\
10 & UC & $01 / 09 / 2012$ & 08 & 7.48 & 904 & 452 \\
11 & I & $07 / 06 / 2012$ & 03 & 6.85 & 814 & 407 \\
12 & I & $12 / 06 / 2012$ & 14 & 6.61 & 2,232 & 1,021 \\
13 & I & $23 / 06 / 2012$ & 08 & 7.34 & 1,517 & 758 \\
14 & I & $27 / 06 / 2012$ & 53 & 7.11 & 1,095 & 551 \\
15 & I & $30 / 06 / 2012$ & 25 & 6.75 & 965 & 487 \\
\hline
\end{tabular}

$U C$ Urban and commercial, $I$ industrial

\section{Analysis}

The Dionex DX120 Ion Chromatograph (Dionex Corporation, Sunnyvale, CA, USA) equipped with an anion separation column, cation separation column and conductivity detector was used for analysis of the anions and cations. The GBC AAS type-932/HG-3000 was used for the analysis of the metals, i.e., $\mathrm{Mn}, \mathrm{Fe}, \mathrm{Cu}, \mathrm{Zn}, \mathrm{Pb}$ and $\mathrm{Hg}$. The E. Merck multielement standard was used for preparation of the calibration curve.

Table 2 Distribution of major ions in runoff water of Raipur city $\left(\mathrm{mg} \mathrm{1}^{-1}\right)$

\begin{tabular}{llrrrrrrrr}
\hline S. no. & Site & $\mathrm{Cl}^{-}$ & $\mathrm{NO}_{3}{ }^{-}$ & $\mathrm{SO}_{4}{ }^{2-}$ & $\mathrm{Na}^{+}$ & $\mathrm{NH}_{4}^{+}$ & $\mathrm{K}^{+}$ & $\mathrm{Mg}^{2+}$ & $\mathrm{Ca}^{2+}$ \\
\hline 1 & $\mathrm{UC}$ & 32 & 46 & 15 & 14 & 13 & 19 & 4 & 16 \\
2 & $\mathrm{UC}$ & 53 & 90 & 404 & 19 & 12 & 65 & 18 & 97 \\
3 & $\mathrm{UC}$ & 51 & 35 & 84 & 23 & 8 & 14 & 11 & 48 \\
4 & $\mathrm{UC}$ & 15 & 46 & 28 & 11 & 10 & 11 & 40 & 119 \\
5 & $\mathrm{UC}$ & 48 & 120 & 99 & 15 & 10 & 26 & 12 & 34 \\
6 & $\mathrm{UC}$ & 57 & 57 & 51 & 9 & 16 & 23 & 19 & 61 \\
7 & $\mathrm{UC}$ & 63 & 51 & 178 & 8 & 10 & 34 & 28 & 116 \\
8 & $\mathrm{UC}$ & 17 & 12 & 25 & 10 & 13 & 4 & 3 & 13 \\
9 & $\mathrm{UC}$ & 41 & 32 & 30 & 14 & 17 & 5 & 7 & 25 \\
10 & $\mathrm{UC}$ & 41 & 168 & 216 & 12 & 68 & 41 & 6 & 21 \\
11 & $\mathrm{I}$ & 551 & 315 & 179 & 93 & 13 & 87 & 64 & 223 \\
12 & $\mathrm{I}$ & 409 & 234 & 158 & 21 & 16 & 57 & 53 & 209 \\
13 & $\mathrm{I}$ & 872 & 671 & 726 & 425 & 527 & 238 & 105 & 392 \\
14 & $\mathrm{I}$ & 184 & 105 & 208 & 173 & 140 & 311 & 57 & 180 \\
15 & $\mathrm{I}$ & 735 & 593 & 925 & 19 & 15 & 11 & 112 & 386 \\
\hline
\end{tabular}

Table 3 Distribution of metals in runoff water of Raipur city $\left(\mathrm{mg} \mathrm{l}^{-1}\right)$

\begin{tabular}{llllllll}
\hline S. no. & Site & $\mathrm{Mn}$ & $\mathrm{Fe}$ & $\mathrm{Cu}$ & $\mathrm{Zn}$ & $\mathrm{Pb}$ & $\mathrm{Hg}$ \\
\hline 1 & $\mathrm{UC}$ & 0.713 & 0.291 & 0.148 & 0.219 & 0.170 & 0.007 \\
2 & $\mathrm{UC}$ & 0.168 & 0.313 & 0.186 & 0.185 & 0.115 & 0.006 \\
3 & $\mathrm{UC}$ & 0.379 & 0.222 & 0.286 & 1.210 & 0.257 & 0.008 \\
4 & $\mathrm{UC}$ & 0.476 & 0.411 & 0.245 & 0.954 & 0.338 & 0.012 \\
5 & $\mathrm{UC}$ & 0.151 & 0.215 & 0.206 & 0.173 & 0.119 & 0.006 \\
6 & $\mathrm{UC}$ & 0.438 & 0.548 & 0.213 & 0.912 & 0.316 & 0.010 \\
7 & $\mathrm{UC}$ & 0.217 & 0.321 & 0.174 & 0.548 & 0.134 & 0.006 \\
8 & $\mathrm{UC}$ & 0.212 & 0.341 & 0.165 & 0.432 & 0.317 & 0.011 \\
9 & $\mathrm{UC}$ & 0.328 & 0.232 & 0.158 & 0.531 & 0.250 & 0.008 \\
10 & $\mathrm{UC}$ & 0.148 & 0.249 & 0.142 & 0.140 & 0.138 & 0.005 \\
11 & $\mathrm{I}$ & 0.207 & 0.690 & 0.189 & 0.656 & 0.270 & 0.014 \\
12 & $\mathrm{I}$ & 1.048 & 0.929 & 0.646 & 1.864 & 0.480 & 0.033 \\
13 & $\mathrm{I}$ & 0.966 & 0.604 & 0.379 & 1.259 & 0.406 & 0.027 \\
14 & $\mathrm{I}$ & 0.289 & 0.691 & 0.134 & 0.213 & 0.210 & 0.009 \\
15 & $\mathrm{I}$ & 0.188 & 0.231 & 0.097 & 0.270 & 0.198 & 0.007 \\
\hline
\end{tabular}

$U C$ Urban and commercial area, $I$ industrial area

Table 4 Range and confidence limit of species $\left(\mathrm{mg} \mathrm{l}^{-1}\right)$

\begin{tabular}{|c|c|c|c|c|}
\hline \multirow[t]{2}{*}{ Species } & \multicolumn{2}{|l|}{$\mathrm{UC}$} & \multicolumn{2}{|l|}{ I } \\
\hline & Range & $\begin{array}{l}\text { Confidence } \\
\text { limit }\end{array}$ & Range & $\begin{array}{l}\text { Confidence } \\
\text { limit }\end{array}$ \\
\hline $\mathrm{Cl}^{-}$ & $15-63$ & $42 \pm 50$ & $184-872$ & $550 \pm 237$ \\
\hline $\mathrm{NO}_{3}^{-}$ & $12-168$ & $66 \pm 29$ & $105-671$ & $384 \pm 210$ \\
\hline $\mathrm{SO}_{4}{ }^{2-}$ & $15-404$ & $113 \pm 76$ & $158-925$ & $439 \pm 316$ \\
\hline $\mathrm{Na}^{+}$ & $8-68$ & $18 \pm 11$ & $13-527$ & $141 \pm 112$ \\
\hline $\mathrm{NH}_{4}^{+}$ & $8-23$ & $14 \pm 3$ & $19-425$ & $146 \pm 147$ \\
\hline $\mathrm{K}^{+}$ & $4-65$ & $24 \pm 12$ & $11-311$ & $142 \pm 195$ \\
\hline $\mathrm{Mg}^{2+}$ & $3-40$ & $15 \pm 7$ & 53-112 & $78 \pm 25$ \\
\hline $\mathrm{Ca}^{2+}$ & $13-119$ & $55 \pm 25$ & $180-392$ & $278 \pm 90$ \\
\hline $\mathrm{Mn}$ & $0.148-0.713$ & $0.323 \pm 0.113$ & $0.188-1.048$ & $0.540 \pm 0.376$ \\
\hline $\mathrm{Fe}$ & $0.215-0.548$ & $0.614 \pm 0.064$ & $0.231-0.929$ & $0.629 \pm 0.222$ \\
\hline $\mathrm{Cu}$ & $0.142-0.286$ & $0.192 \pm 0.029$ & $0.097-0.646$ & $0.289 \pm 0.199$ \\
\hline $\mathrm{Zn}$ & $0.140-1.210$ & $0.530 \pm 0.235$ & $0.213-1.864$ & $0.852 \pm 0.616$ \\
\hline $\mathrm{Pb}$ & $0.115-0.338$ & $0.215 \pm 0.056$ & $0.198-0.480$ & $0.313 \pm 0.110$ \\
\hline $\mathrm{Hg}$ & $0.005-0.012$ & $0.008 \pm 0.002$ & $0.007-0.033$ & $0.018 \pm 0.010$ \\
\hline
\end{tabular}

Statistical analysis

Cluster analysis (CA) and factor analysis (FA) were performed on the standardized datasets whose mean and variance were set to zero and one, respectively. This procedure minimizes the effects of differences in measurements units or variance and to render the data dimensionless (Einax et al. 1997). The main aim of CA is grouping of water samples into class or clusters, so that objects within a class 
Fig. 2 Spatial variation of ions and metals in runoff water

Fig. 3 Seasonal variation of ions and metals in UC site
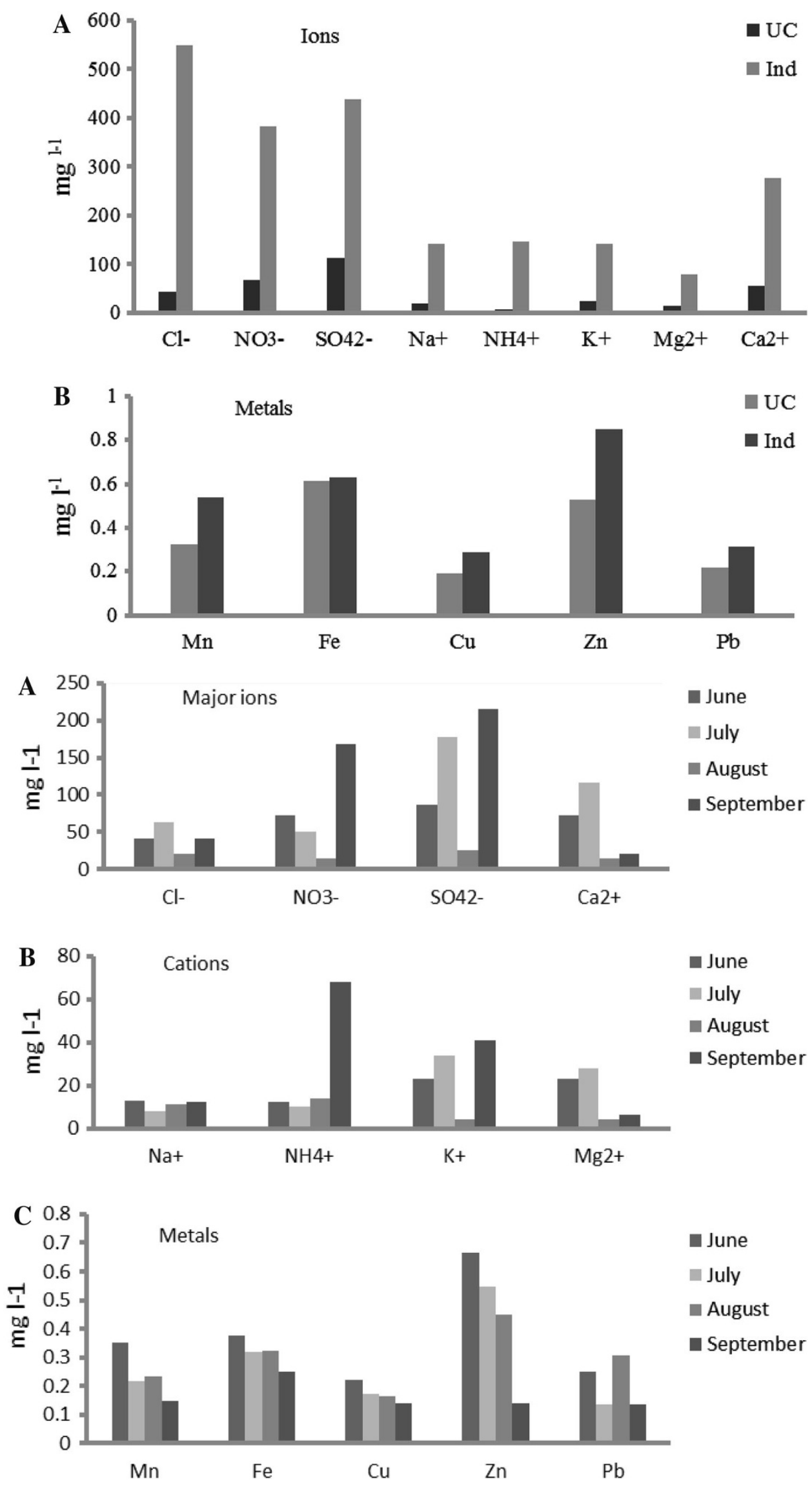
Fig. 4 Ef value of ions and metals in runoff water

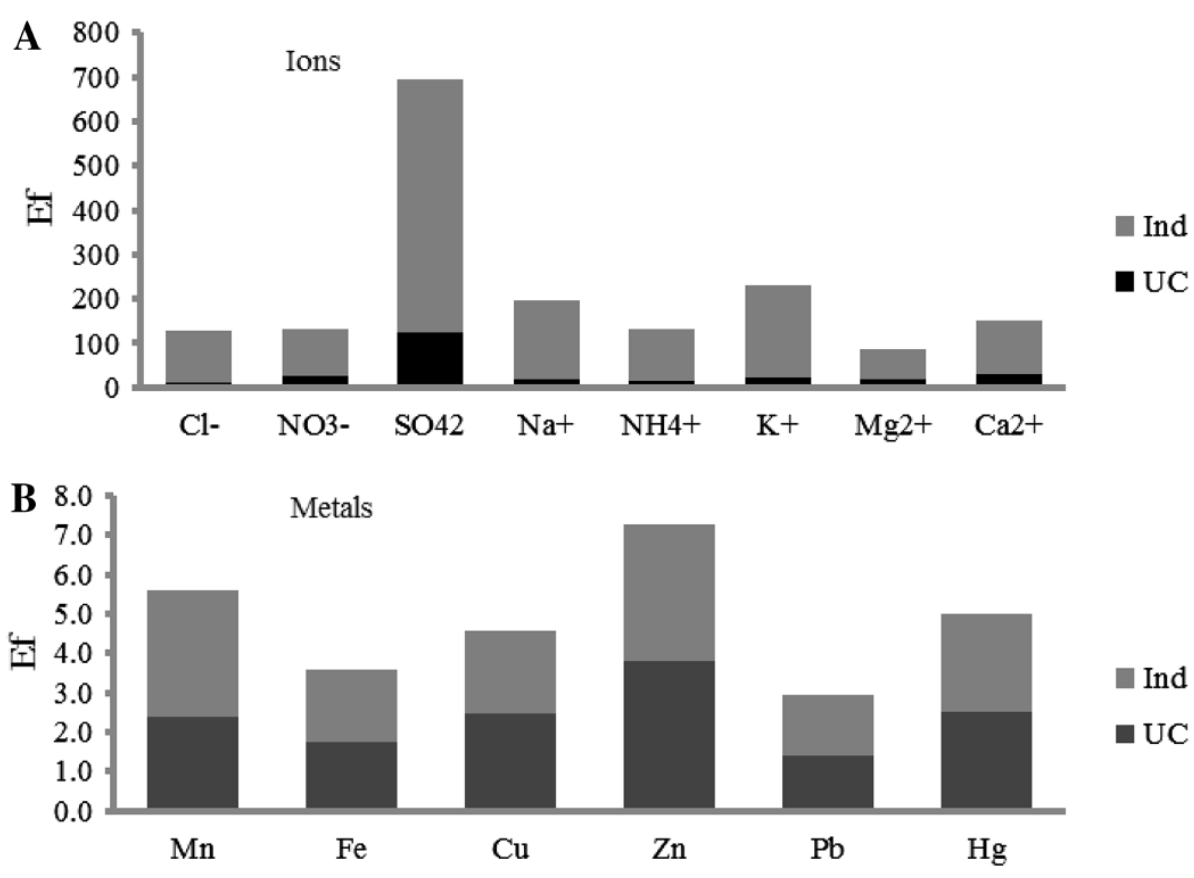

are similar to each other but different from those of the other classes.

The common approach, hierarchical cluster analysis (HCA), is used for forming clusters sequentially using Ward's method (Simeonov et al. 2003: Ambade 2014). This method starts with the most similar pair of objects and forms higher clusters step by step. The process of forming and joining clusters is repeated until a single cluster containing all the samples is obtained.

In factor FA, which is a multivariate statistical method, the general relationship between measured variables is highlighted by showing multivariate patterns that may help to classify the original data. The method makes easy the reduction, organization and transformation of the original data by the use of intricate mathematical techniques. The result is a simple form of factor model in which the interpretation of dominant factors was made by taking into account the highest factor loadings on chemical elements. The number of factors to extract was determined by the criterion proposed by Kaiser (1958). This study retained only factors with eigenvalues that exceed one. The statistical analysis was done using STATISTICA 7.1 program for Windows.

\section{Results and discussion}

Physical characteristics

The physical characteristics, i.e., water level, $\mathrm{pH}$, conductivity and TDS values of runoff waters are summarized in
Table 5 Fluxes of ions and metals

\begin{tabular}{|c|c|c|c|c|}
\hline \multirow[t]{2}{*}{ Element } & \multicolumn{2}{|l|}{ Urban site } & \multicolumn{2}{|l|}{ Industrial site } \\
\hline & $\begin{array}{l}\text { VWM } \\
\text { concentration } \\
\left(\mathrm{mg} \mathrm{l}^{-1}\right)\end{array}$ & $\begin{array}{l}\text { Fluxes } \\
\left(\mathrm{mg} \mathrm{m}^{-2}\right)\end{array}$ & $\begin{array}{l}\text { VWM } \\
\text { concentration } \\
\left(\mathrm{mg} \mathrm{l}^{-1}\right)\end{array}$ & $\begin{array}{l}\text { Fluxes } \\
\left(\mathrm{mg} \mathrm{m}^{-2}\right)\end{array}$ \\
\hline $\mathrm{Cl}^{-}$ & 40 & 9,635 & 412 & 98,987 \\
\hline $\mathrm{NO}_{3}{ }^{-}$ & 65 & 15,586 & 291 & 69,854 \\
\hline $\mathrm{SO}_{4}{ }^{2-}$ & 91 & 21,950 & 415 & 99,509 \\
\hline $\mathrm{Na}^{+}$ & 12 & 2,870 & 132 & 31,729 \\
\hline $\mathrm{NH}_{4}^{+}$ & 14 & 3,298 & 119 & 28,600 \\
\hline $\mathrm{K}^{+}$ & 22 & 5,290 & 191 & 45,952 \\
\hline $\mathrm{Mg}^{2+}$ & 20 & 4,805 & 74 & 17,697 \\
\hline $\mathrm{Ca}^{2+}$ & 67 & 16,151 & 252 & 60,398 \\
\hline $\mathrm{Mn}$ & 0.31 & 75 & 0.42 & 100 \\
\hline $\mathrm{Fe}$ & 0.72 & 173 & 0.60 & 145 \\
\hline $\mathrm{Cu}$ & 0.21 & 49 & 0.22 & 52 \\
\hline $\mathrm{Zn}$ & 0.61 & 145 & 0.55 & 131 \\
\hline $\mathrm{Pb}$ & 0.24 & 58 & 0.26 & 63 \\
\hline $\mathrm{Hg}$ & 0.01 & 2 & 0.01 & 3 \\
\hline
\end{tabular}

Table 1 . The value of $\mathrm{pH}$, conductivity and TDS in the urban and commercial (UC) site ranged from 6.20 to 7.48, 659 to $1893 \mu \mathrm{S}$ and 395 to $1,009 \mathrm{mg} \mathrm{l}^{-1}$ with a mean value of $6.9 \pm 0.4,1081 \pm 211 \mu \mathrm{S} \mathrm{cm}^{-1}$ and $516 \pm$ $113 \mathrm{mg} \mathrm{l}^{-1}$, respectively. The volume weighted mean (VWM) value for $\mathrm{pH}$, conductivity and TDS at the UC site is $7.1,1,077 \mu \mathrm{S} \mathrm{cm}^{-1}$ and $590 \mathrm{mg} \mathrm{l}^{-1}$, respectively. The value of conductivity and TDS is found to be increased in the industrial site due to higher ion contents. 
Table 6 Correlation matrix of chemical species in industrial runoff water

\begin{tabular}{|c|c|c|c|c|c|c|c|c|c|c|c|c|c|}
\hline & $\mathrm{Cl}^{-}$ & $\mathrm{NO}_{3}^{-}$ & $\mathrm{SO}_{4}{ }^{2-}$ & $\mathrm{Na}^{+}$ & $\mathrm{K}^{+}$ & $\mathrm{Mg}^{2+}$ & $\mathrm{Ca}^{2+}$ & $\mathrm{Mn}$ & $\mathrm{Fe}$ & $\mathrm{Cu}$ & $\mathrm{Zn}$ & $\mathrm{Pb}$ & $\mathrm{Hg}$ \\
\hline $\mathrm{Cl}^{-}$ & 1.00 & & & & & & & & & & & & \\
\hline $\mathrm{NO}_{3}{ }^{-}$ & 0.98 & 1.00 & & & & & & & & & & & \\
\hline $\mathrm{SO}_{4}^{2-}$ & 0.79 & 0.89 & 1.00 & & & & & & & & & & \\
\hline $\mathrm{Na}^{+}$ & 0.82 & 0.42 & 0.24 & 1.00 & & & & & & & & & \\
\hline $\mathrm{K}^{+}$ & -0.32 & -0.24 & -0.20 & 0.72 & 1.00 & & & & & & & & \\
\hline $\mathrm{Mg}^{2+}$ & 0.87 & 0.94 & 0.98 & 0.35 & -0.17 & 1.00 & & & & & & & \\
\hline $\mathrm{Ca}^{2+}$ & 0.92 & 0.98 & 0.96 & 0.39 & -0.20 & 0.98 & 1.00 & & & & & & \\
\hline $\mathrm{Mn}$ & 0.20 & 0.14 & 0.00 & 0.39 & 0.00 & 0.00 & 0.10 & 1.00 & & & & & \\
\hline $\mathrm{Fe}$ & -0.54 & -0.64 & -0.87 & 0.00 & -0.25 & -0.84 & -0.73 & 0.57 & 1.00 & & & & \\
\hline $\mathrm{Cu}$ & 0.00 & 0.00 & -0.33 & 0.00 & -0.14 & -0.33 & 0.00 & 0.92 & 0.72 & 1.00 & & & \\
\hline $\mathrm{Zn}$ & 0.14 & 0.00 & 0.78 & -0.10 & -0.20 & -0.22 & 0.00 & 0.93 & 0.66 & 0.98 & 1.00 & & \\
\hline $\mathrm{Pb}$ & 0.17 & 0.00 & 0.22 & 0.22 & 0.00 & -0.20 & 0.00 & 0.96 & 0.66 & 0.97 & 0.99 & 1.00 & \\
\hline $\mathrm{Hg}$ & 0.17 & 0.22 & 0.22 & 0.26 & 0.00 & -0.20 & 0.00 & 0.97 & 0.68 & 0.96 & 0.96 & 1.00 & 1.00 \\
\hline
\end{tabular}

Fig. 5 Dendrogram of runoff water sample in Raipur in UC site
Dendrogram of 10 Observations

Ward's method

Square Euclidean Distances

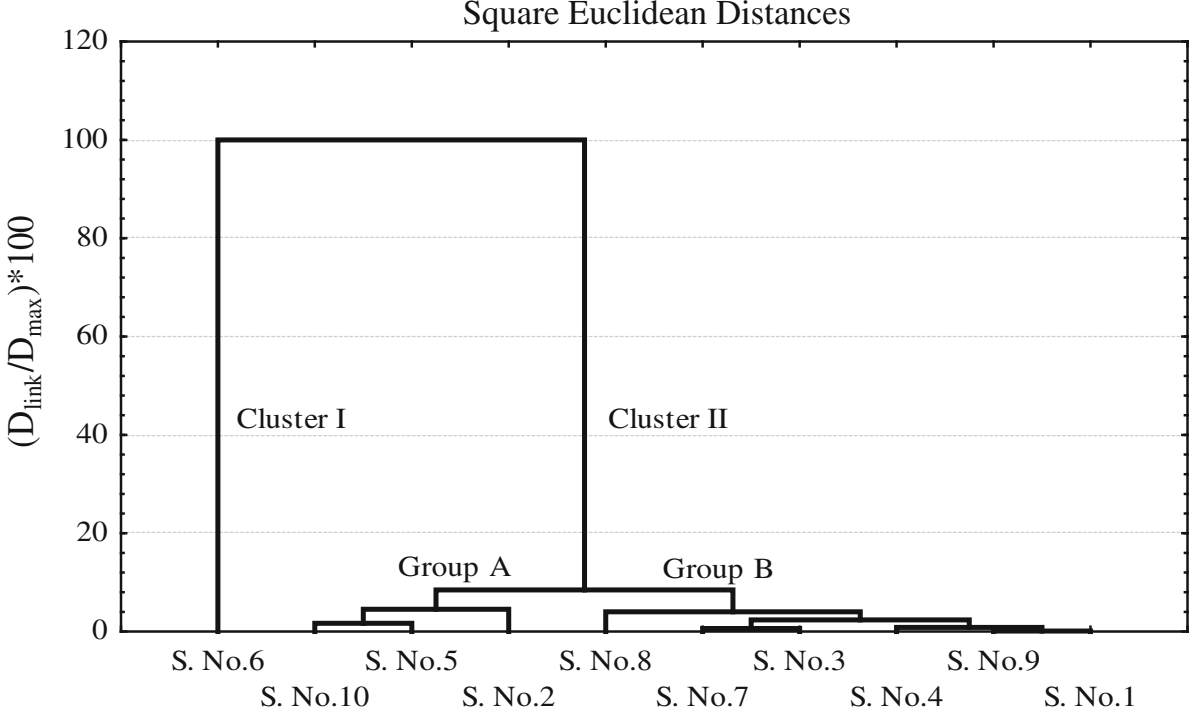

Chemical characteristics

The concentration, range and confidence limit (at $95 \%$ probability) of ions $\left(\mathrm{Cl}^{-}, \mathrm{NO}_{3}{ }^{-}, \mathrm{SO}_{4}{ }^{2-}, \mathrm{NH}_{4}{ }^{+}, \mathrm{Na}^{+}, \mathrm{K}^{+}\right.$, $\mathrm{Mg}^{2+}$ and $\mathrm{Ca}^{2+}$ ) and metals ( $\mathrm{Mn}, \mathrm{Fe}, \mathrm{Cu}, \mathrm{Zn}, \mathrm{Pb}$ and $\mathrm{Hg}$ ) in the runoff water are summarized in Tables 2, 3 and 4. The volume weighted mean (VWM) value for $\mathrm{Cl}^{-}, \mathrm{NO}_{3}{ }^{-}$, $\mathrm{SO}_{4}{ }^{2-}, \mathrm{NH}_{4}{ }^{+}, \mathrm{Na}^{+}, \mathrm{K}^{+}, \mathrm{Mg}^{2+}$ and $\mathrm{Ca}^{2+}$ in the UC site is observed to be $40,65,91,12,14,22,20$ and $67 \mathrm{mg} \mathrm{l}^{-1}$, respectively. Their concentrations are found to increase several folds higher in the industrial site (Fig. 2a). The sum of the total mean ratio of the $(\Sigma$ anion $] /[\Sigma$ cation $)$ in urban and industrial dirt was found to be 1.1 and 1.0, respectively. The VWM values for $\mathrm{Mn}, \mathrm{Fe}, \mathrm{Cu}, \mathrm{Zn}, \mathrm{Pb}$ and $\mathrm{Hg}$ are $0.314,0.720,0.205,0.606,0.241$ and $0.009 \mathrm{mg} \mathrm{l}^{-1}$, respectively, in the $\mathrm{UC}$ site. The metal contents are increased significantly in the industrial site (Fig. 2b). Most of species showed the lowest content during the month of July and August due to dilution by the higher rain precipitation (Fig. 3a-c).

\section{Effect of rain}

The amount and quality of rain affect the contamination levels of runoff water. The enrichment factor, Ef $\left(C_{\text {runoff }}\right)$ $C_{\text {rain }}$ ), of 14 species is summarized in Fig. 4. The Ef value 
Fig. 6 Dendrogram of the runoff water samples in Raipur in industrial area
Dendrogram of 5 Observations

Ward's method

Square Euclidean Distances

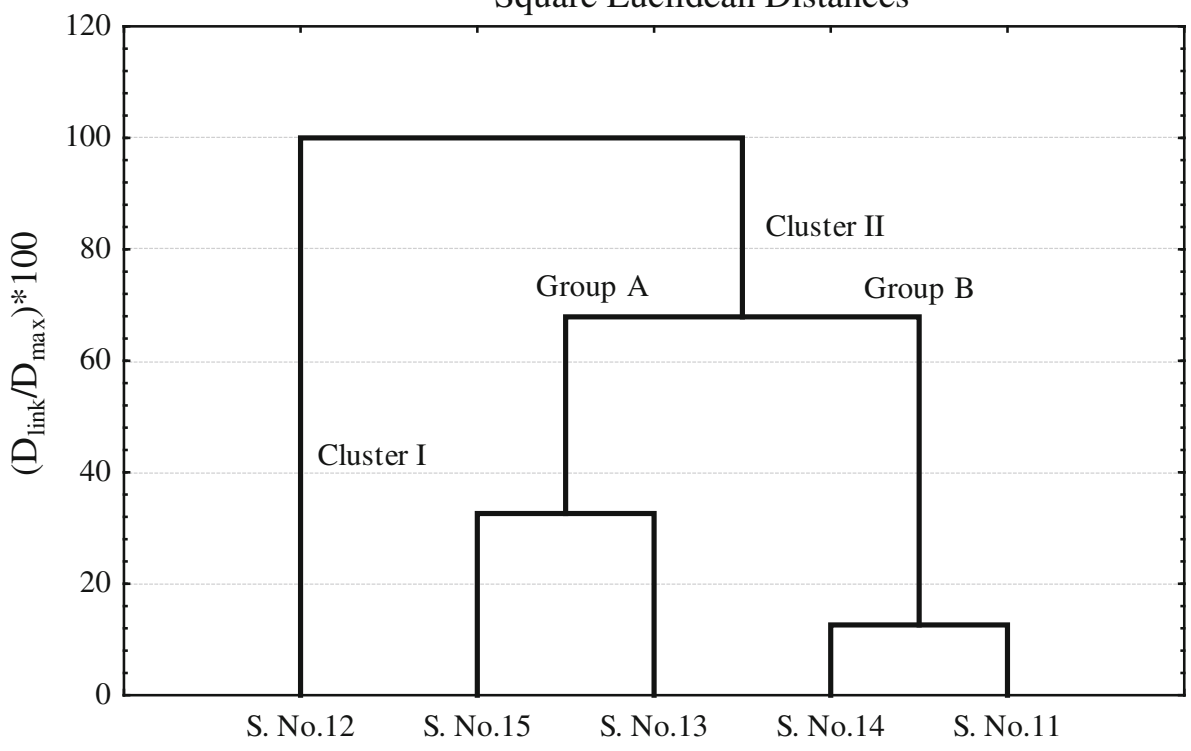

of ions $\mathrm{Cl}^{-}, \mathrm{NO}_{3}{ }^{-}, \mathrm{SO}_{4}{ }^{2-}, \mathrm{Na}^{+}, \mathrm{K}^{+}, \mathrm{Mg}^{2+}$ and $\mathrm{Ca}^{2+}$ in the industrial site is found to be several folds higher due to anthropogenic emissions. However, the Ef value of metals $\mathrm{Mn}, \mathrm{Fe}, \mathrm{Cu}, \mathrm{Zn}, \mathrm{Pb}$ and $\mathrm{Hg}$ in the $\mathrm{UC}$ site is found to be comparable, whereas a higher Ef value of $\mathrm{Cu}$ and $\mathrm{Zn}$ is observed in the urban site due to non-vehicular emissions. The rain content of four metals $\mathrm{Cu}, \mathrm{Zn}, \mathrm{Pb}$ and $\mathrm{Hg}$ with the runoff content is correlated fairly $(r=0.87-0.89)$ as their major fractions are contributed by the rain. The amount of rain precipitated with the runoff content of metals $\mathrm{Mn}, \mathrm{Fe}, \mathrm{Cu}, \mathrm{Pb}$ and $\mathrm{Hg}$ has also a fair correlation $(r=0.73-0.92)$.

\section{Removal fluxes}

The Central Water Commission has estimated the total annual surface runoff in the in India only $36 \%$ of total annual surface runoff (188 million hectare metres) is put to use (CPCB 1995). The average rainfall in Raipur city in the monsoon period, 2012 was $67 \mathrm{~cm}$. It means $24 \mathrm{~cm}$ water was run off. The amount of species $\mathrm{Cl}^{-}, \mathrm{NO}_{3}{ }^{-}, \mathrm{SO}_{4}{ }^{2-}$, $\mathrm{NH}_{4}{ }^{+}, \mathrm{Na}^{+}, \mathrm{K}^{+}, \mathrm{Mg}^{2+}, \mathrm{Ca}^{2+}, \mathrm{Mn}, \mathrm{Fe}, \mathrm{Cu}, \mathrm{Zn}, \mathrm{Pb}$ and $\mathrm{Hg}$ removed from the runoff water is summarized in Table 5. The very high fraction of nutrients: $\mathrm{SO}_{4}{ }^{2-}, \mathrm{NO}_{3}{ }^{-}$and $\mathrm{Cl}^{-}$ is removed from the runoff water. The removal fluxes of species in decreasing order found were $\mathrm{SO}_{4}{ }^{2-}>$ $\mathrm{NO}_{3}{ }^{-}>\mathrm{Ca}^{2+}>\mathrm{Cl}^{-}>\mathrm{K}^{+}>\mathrm{Mg}^{2+}>\mathrm{NH}_{4}{ }^{+}>\mathrm{Na}^{+}>\mathrm{Fe}$ $>\mathrm{Zn}>\mathrm{Mn}>\mathrm{Pb}>\mathrm{Cu}>\mathrm{Hg}$. The total fluxes of 14 species removed from the runoff water in the urban and industrial site are 80 and $453 \mathrm{~g} \mathrm{~m}^{-2}$, respectively.
Correlation

The correlation matrix of the species in the industrial site is presented in Table 6. The $\mathrm{Cl}^{-}, \mathrm{NO}_{3}{ }^{-}, \mathrm{SO}_{4}{ }^{2-}, \mathrm{Mg}^{2+}$ and $\mathrm{Ca}^{2+}$ contents among themselves have fair to excellent correlation ( $r=0.79-0.99)$ at the industrial site. Similarly, metals $\mathrm{Mn}, \mathrm{Cu}, \mathrm{Zn}, \mathrm{Pb}$ and $\mathrm{Hg}$ among themselves have good correlation $(r=0.92-1.00)$. However, Fe has fair positive correlation with the heavy metals $(r=0.57-0.72)$, and negative correlation ions $\mathrm{Cl}^{-}, \mathrm{NO}_{3}{ }^{-}, \mathrm{SO}_{4}{ }^{2-}, \mathrm{Mg}^{2+}$ and $\mathrm{Ca}^{2+}(r=-0.54-0.87)$. The $\mathrm{Na}^{+}$has fair correlation ( $r=0.71-0.82$ ) only with $\mathrm{Cl}^{-}$and $\mathrm{K}^{+}$. However, no correlation trend is observed in the UC site, which may be due to their emissions by the multiple sources.

\section{Cluster analysis}

The dendrogram of the runoff water samples in the UC and industrial sites is shown in Figs. 5 and 6. In the UC site, Cluster I contains sample No. 6, which can be considered as an outlaw. Cluster II is composed of two groups (A and B) of samples. Group A contains the samples No. 2, 5 and 10, while group B contains the samples No. 1, 3, 4, 7, 8 and 9. Group A and group B in cluster II are joined at $\left(D_{\text {link }} /\right.$ $\left.D_{\max }\right) \times 100<16$. In general, the mineralization of the runoff water samples and median values of metals, such as $\mathrm{Fe}, \mathrm{Mn}, \mathrm{Zn}$ and $\mathrm{Pb}$, differentiate group A from group $\mathrm{B}$ in cluster II (Fig. 7). The high difference in median values between certain parameters $\left(\mathrm{EC}, \mathrm{NO}_{3}{ }^{-}, \mathrm{SO}_{4}{ }^{2-}\right.$ and $\left.\mathrm{K}^{+}\right)$in groups $\mathrm{A}$ and $\mathrm{B}$ could indicate that the runoff water 
Fig. 7 Comparison of physicochemical parameters between clusters I and II in UC site
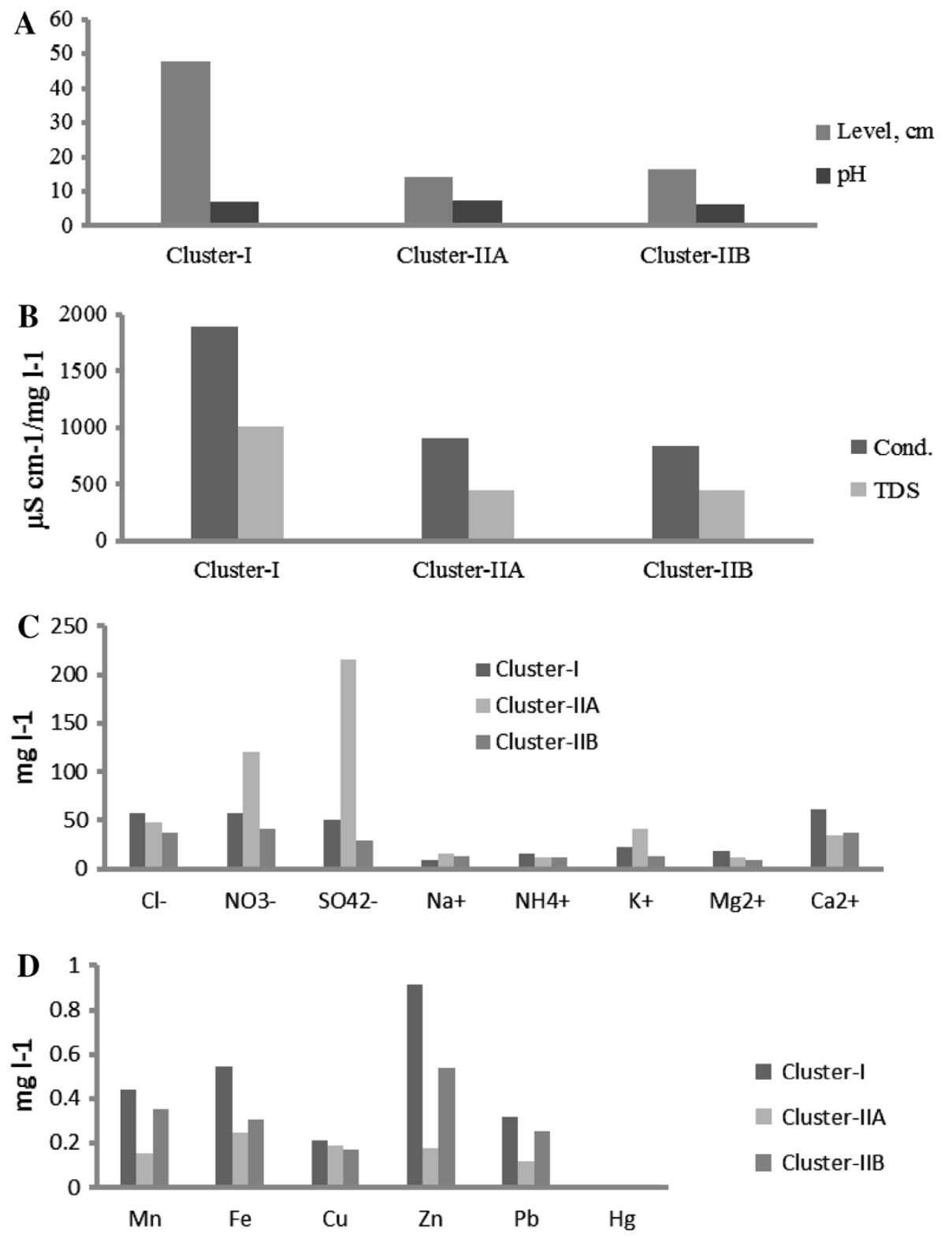

samples are not affected by similar sources. The distribution of physico-chemical parameters and metal contents in runoff water samples between cluster I and cluster II revealed well that sample No. 6 is an outlier, which presents the highest values of the parameters EC, TDS, Mn, Fe and $\mathrm{Zn}$ (Fig. 7). The same study was done earlier (Ambade and Ghosh 2013).

In industrial site, Cluster I contains sample No. 12, which can be considered as an outlaw (Fig. 6). Cluster II is composed of two groups (A and B) of samples. Group A contains the samples No. 13 and 15 while group B contains the samples No. 11 and 14. Group A and group B in cluster II are joined at $\left(D_{\text {link }} / D_{\text {max }}\right) \times 100>60$. This denotes dissimilarity between the two groups. In general, the mineralization of the runoff water samples and median values of metals, such as $\mathrm{Fe}, \mathrm{Mn}, \mathrm{Zn}$ and $\mathrm{Pb}$, differentiate group A from group B in cluster II. The high difference in median values between certain parameters $\left(\mathrm{EC}, \mathrm{NO}_{3}{ }^{-}\right.$, $\mathrm{SO}_{4}{ }^{2-}$ and $\mathrm{K}^{+}$) in groups $\mathrm{A}$ and $\mathrm{B}$ could indicate that the runoff water samples were not affected by similar sources (Fig. 8). The difference between cluster I and cluster II is highlighted by the parameters $\mathrm{pH}, \mathrm{EC}$, TDS and metals ( $\mathrm{Mn}, \mathrm{Fe}, \mathrm{Cu}, \mathrm{Zn}$ and $\mathrm{Pb}$ ) (Fig. 8). The $\mathrm{Hg}$ content does not discriminate the two clusters.

Factor analysis

There are multiple ways to extract factors. Normalized varimax rotation was applied to the extracted factors. Tables 7, 8 summarize the sorted FA results, including the 
Fig. 8 Comparison of physicochemical parameters between clusters I and II in industrial site
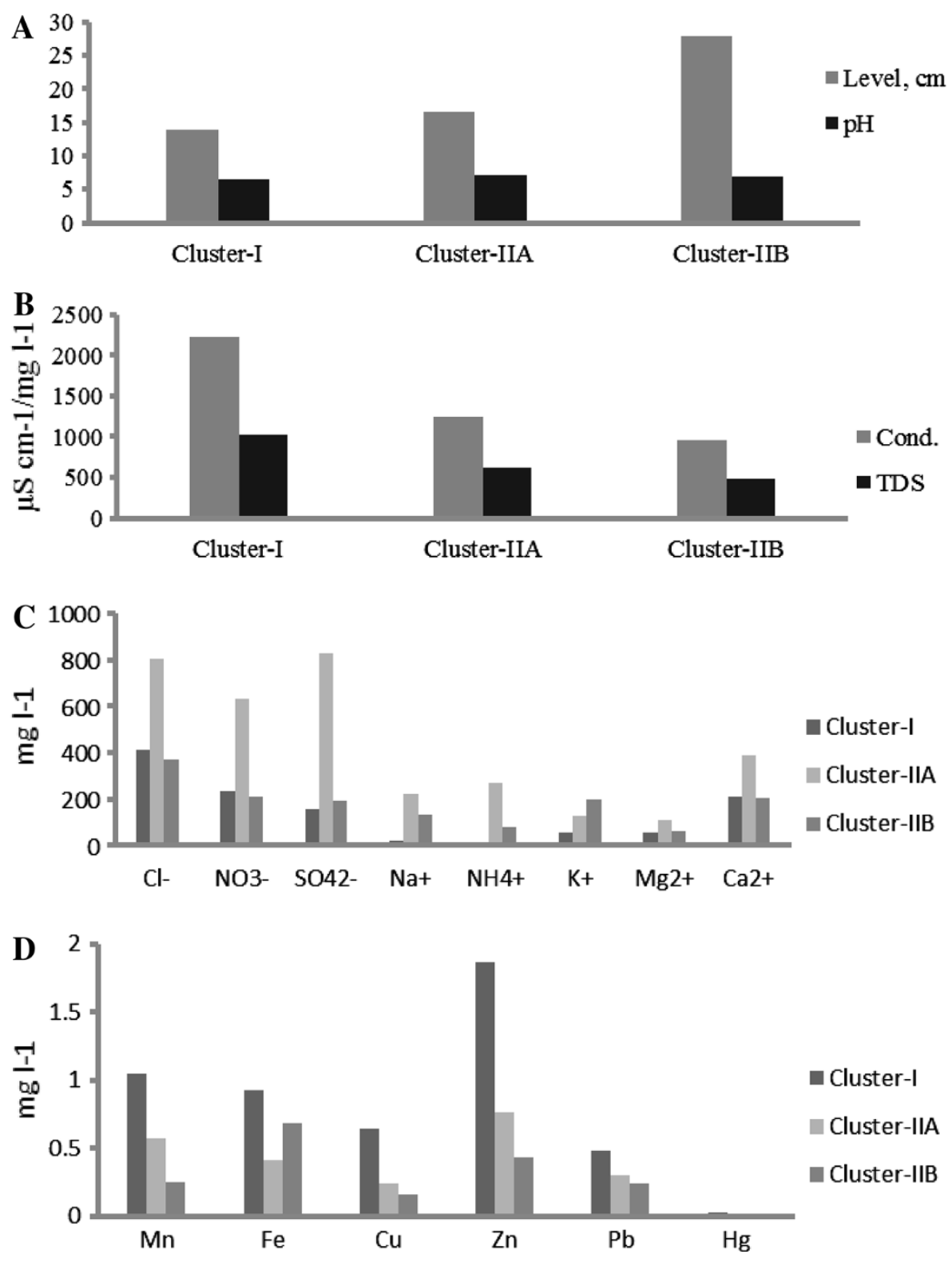

variable loadings, eigenvalues and variance explained by each factor. Six factors have accounted for $92.12 \%$ of the total variance in the UC site. Factor 1 accounts for $34.09 \%$ of the total variance and metals, i.e., $\mathrm{Pb}$ and $\mathrm{Hg}$ are strongly loaded with a positive value. The parameters of $\mathrm{K}^{+}, \mathrm{SO}_{4}{ }^{2-}$ and $\mathrm{Cl}^{-}$with negative loading values are opposite in relation to metals, i.e., $\mathrm{Pb}$ and $\mathrm{Hg}$. On UC site, these metals and major ions could come from building materials and domestic wastes, respectively. Factor 2 contributes to $21.21 \%$ of the total variance. Ions $\mathrm{Mg}^{2+}$ and $\mathrm{Ca}^{2+}$ are strongly loaded on factor 2 with positive values. The factor loading indicated that $\mathrm{Mg}^{2+}$ and $\mathrm{Ca}^{2+}$ presented good correlation with $\mathrm{pH}$ value. Loading values on factor 2 shows $\mathrm{pH}$ as a controlling factor of the alkaline earth elements $\left(\mathrm{Ca}^{2+}\right.$ and $\left.\mathrm{Mg}^{2+}\right)$. Factor 3 accounts for $14.19 \%$ of the total variance, and metals $\mathrm{Cu}$ and $\mathrm{Zn}$ are strongly associated with factor 3 with positive loading values, and they presented a good correlation with the concentration of $\mathrm{Na}^{+}$. Therefore, the results of FA method suggest that these metals have a different source when compared to $\mathrm{Pb}$ and $\mathrm{Hg}$. However, one cannot conclude whether the origin of $\mathrm{Cu}$ and $\mathrm{Zn}$ comes from, mainly, natural or anthropogenic sources. Factor 4 contributes to $10.50 \%$ of the total variance and included EC and TDS, which indicate the mineralization of the runoff water. Factor 5 accounts for $6.47 \%$ of the total variance, includes $\mathrm{Mn}$ which is a major element present in the soil and negatively loaded to factor 5. At the sight of the factor loadings (factors 1, 3 and 5), one can say that the distribution of metals $(\mathrm{Pb}, \mathrm{Hg}, \mathrm{Cu}$ and $\mathrm{Zn}$ ) in the runoff water is not controlled by oxy-hydroxides 
Table 7 Loading for varimax rotated factor, eigenvalues and variance in urban site

\begin{tabular}{|c|c|c|c|c|c|c|}
\hline Parameter & $\begin{array}{l}\text { Factor } \\
1\end{array}$ & $\begin{array}{l}\text { Factor } \\
2\end{array}$ & $\begin{array}{l}\text { Factor } \\
3\end{array}$ & $\begin{array}{l}\text { Factor } \\
4\end{array}$ & $\begin{array}{l}\text { Factor } \\
5\end{array}$ & $\begin{array}{l}\text { Factor } \\
6\end{array}$ \\
\hline level & 0.31 & 0.63 & 0.05 & 0.52 & 0.26 & 0.00 \\
\hline $\mathrm{pH}$ & -0.45 & 0.71 & -0.22 & 0.07 & 0.06 & -0.43 \\
\hline $\mathrm{EC}$ & -0.05 & 0.09 & 0.07 & 0.96 & -0.21 & -0.06 \\
\hline TDS & 0.14 & -0.01 & -0.02 & 0.98 & 0.08 & 0.04 \\
\hline $\mathrm{Cl}^{-}$ & -0.83 & 0.03 & 0.16 & 0.34 & -0.13 & 0.09 \\
\hline $\mathrm{NO}_{3}^{-}$ & -0.50 & 0.04 & -0.09 & 0.05 & 0.07 & $-\mathbf{0 . 8 3}$ \\
\hline $\mathrm{SO}_{4}^{2-}$ & -0.82 & 0.18 & 0.02 & -0.20 & 0.32 & -0.16 \\
\hline $\mathrm{Na}^{+}$ & -0.34 & -0.38 & 0.71 & -0.38 & -0.06 & 0.07 \\
\hline $\mathrm{NH}_{4}^{+}$ & -0.08 & -0.20 & -0.22 & -0.01 & 0.04 & -0.88 \\
\hline $\mathrm{K}^{+}$ & -0.86 & 0.20 & -0.08 & -0.03 & 0.15 & -0.21 \\
\hline $\mathrm{Mg}^{2+}$ & 0.05 & 0.97 & 0.18 & 0.06 & -0.10 & 0.10 \\
\hline $\mathrm{Ca}^{2+}$ & -0.22 & 0.91 & 0.17 & -0.04 & -0.02 & 0.23 \\
\hline $\mathrm{Mn}$ & 0.41 & -0.09 & 0.02 & 0.10 & -0.77 & 0.30 \\
\hline $\mathrm{Fe}$ & 0.51 & -0.24 & -0.26 & 0.01 & 0.70 & 0.27 \\
\hline $\mathrm{Cu}$ & 0.15 & 0.30 & 0.90 & 0.10 & -0.02 & 0.16 \\
\hline $\mathrm{Zn}$ & 0.41 & 0.25 & 0.70 & 0.22 & -0.18 & 0.27 \\
\hline $\mathrm{Pb}$ & 0.84 & 0.06 & 0.28 & 0.30 & 0.07 & 0.22 \\
\hline $\mathrm{Hg}$ & 0.84 & 0.22 & 0.18 & 0.23 & 0.14 & 0.32 \\
\hline Eigenvalue & 6.14 & 3.82 & 2.55 & 1.89 & 1.16 & 1.02 \\
\hline $\begin{array}{l}\% \text { Total } \\
\text { variance }\end{array}$ & 34.09 & 21.21 & 14.19 & 10.50 & 6.47 & 5.67 \\
\hline $\begin{array}{l}\% \text { Cumulative } \\
\text { variance }\end{array}$ & 34.09 & 55.30 & 69.48 & 79.98 & 86.45 & 92.12 \\
\hline
\end{tabular}

Higher values are indicated in bold

of Mn. Factor 6 contributes to $5.67 \%$ of the total variance, and it is negatively loaded with inorganic nitrogen ions $\left(\mathrm{NO}_{3}{ }^{-}\right.$and $\left.\mathrm{NH}_{4}{ }^{+}\right)$. This indicates that the distribution of metals in the runoff water is not controlled by organic matter (OM). In conclusion, FA results indicated the factors which could control the distribution of metals and major ions in the runoff water. Various activities in urban areas such as building renovation, excavations, road construction are dispersed within the urban area (Cornelissen et al. 2008; Jartun et al. 2008).

However, in industrial site, four factors were extracted which accounted for $100 \%$ of the total variance. Factor 1 accounts for $42.69 \%$ of the total variance. The factor loadings indicate that metals such as $\mathrm{Mn}, \mathrm{Cu}, \mathrm{Zn}, \mathrm{Pb}$ and $\mathrm{Hg}$ are strongly and positively loaded. These metals present a good correlation to EC and TDS. This indicates a high content of these metals in runoff water collected from the industrial area. Nonpoint source pollution is the primary cause of polluted runoff water and comes from many diffuse or scattered sources, many of which are the result of human activities. Factor 1 suggested that these metals have their origin associated with industrial activities in the study area. Factor I is related to the transport of metals in runoff
Table 8 Loading for varimax rotated factor, eigenvalues and variance in industrial site

\begin{tabular}{lrrrr}
\hline Parameter & Factor 1 & Factor 2 & Factor 3 & Factor 4 \\
\hline Level & -0.33 & -0.27 & 0.12 & $-\mathbf{0 . 9 0}$ \\
$\mathrm{pH}$ & -0.13 & 0.16 & $\mathbf{0 . 9 8}$ & -0.03 \\
$\mathrm{EC}$ & $\mathbf{0 . 9 8}$ & -0.10 & -0.08 & -0.14 \\
$\mathrm{TDS}$ & $\mathbf{0 . 9 9}$ & -0.06 & -0.02 & -0.16 \\
$\mathrm{Cl}^{-}$ & 0.08 & $\mathbf{0 . 8 7}$ & 0.13 & 0.47 \\
$\mathrm{NO}_{3}{ }^{-}$ & 0.04 & $\mathbf{0 . 9 4}$ & 0.16 & 0.28 \\
$\mathrm{SO}_{4}{ }^{2-}$ & -0.15 & $\mathbf{0 . 9 8}$ & 0.05 & -0.13 \\
$\mathrm{Na}^{+}$ & 0.14 & 0.24 & $\mathbf{0 . 9 5}$ & 0.13 \\
$\mathrm{NH}_{4}{ }^{+}$ & 0.26 & 0.38 & $\mathbf{0 . 8 9}$ & 0.06 \\
$\mathrm{~K}^{+}$ & -0.08 & -0.31 & $\mathbf{0 . 8 9}$ & -0.33 \\
$\mathrm{Mg}^{2+}$ & -0.17 & $\mathbf{0 . 9 8}$ & 0.14 & 0.02 \\
$\mathrm{Ca}^{2+}$ & 0.00 & $\mathbf{0 . 9 8}$ & 0.15 & 0.10 \\
$\mathrm{Mn}$ & $\mathbf{0 . 9 7}$ & 0.07 & 0.24 & 0.06 \\
$\mathrm{Fe}$ & 0.60 & $-\mathbf{0 . 7 8}$ & 0.12 & 0.16 \\
$\mathrm{Cu}$ & $\mathbf{0 . 9 7}$ & -0.16 & -0.08 & 0.14 \\
$\mathrm{Zn}$ & $\mathbf{0 . 9 5}$ & -0.07 & -0.04 & 0.29 \\
$\mathrm{~Pb}$ & $\mathbf{0 . 9 6}$ & -0.05 & 0.08 & 0.27 \\
$\mathrm{Hg}$ & $\mathbf{0 . 9 5}$ & -0.06 & 0.11 & 0.27 \\
$\mathrm{Eigenvalue}$ & 7.68 & 5.99 & 3.30 & 1.02 \\
$\%$ Total variance & 42.69 & 33.30 & 18.32 & 5.69 \\
$\%$ Cumulative variance & 42.69 & 75.99 & 94.31 & 100.0 \\
\hline
\end{tabular}

Higher values are indicated in bold

water in the study area. Factor 2 accounts for $33.30 \%$ of the total variance and included $\mathrm{Cl}^{-}, \mathrm{NO}_{3}{ }^{-}, \mathrm{SO}_{4}{ }^{2-}, \mathrm{Mg}^{2+}$, and $\mathrm{Ca}^{2+}$ with strong and positive loading values. Iron is negatively loaded on factor 2 and in opposite with metals loaded in factor 1 . Factor 2 highlights the presence of dissolved salts in the runoff water. Factor 3 accounts for $18.32 \%$ of the total variance and has strong positive loading values on $\mathrm{pH}, \mathrm{Na}^{+}, \mathrm{NH}_{4}{ }^{+}$and $\mathrm{K}^{+}$. It could suggest different impacts, which contribute to runoff water quality such as the breakdown of the organic materials and illicit discharge of industrial wastewater. Factor 4 explains $5.69 \%$ of the total variance and has a negative loading value of the parameter level, which is not a controlling factor neither in the distribution of heavy metals nor in the presence of dissolved salts in runoff water. The result of factor analysis highlighted the same parameters which discriminate the clusters in HCA.

\section{Toxicities}

The runoff waters flow into water reservoirs and rivers percolating into ground water. Exposure to high content of ions and metals over the course of years is associated with toxic effects. The permissible limits for $\mathrm{Cl}^{-}, \mathrm{NO}_{3}{ }^{-}, \mathrm{SO}_{4}{ }^{2-}$, $\mathrm{Mg}^{2+}, \mathrm{Ca}^{2+}, \mathrm{Mn}, \mathrm{Fe}, \mathrm{Cu}, \mathrm{Zn}, \mathrm{Pb}$ and $\mathrm{Hg}$ in drinking water 
reported are $250,45,200,30,75,0.1,0.3,0.05,2.0,0.05$ and $0.001 \mathrm{mg}^{-1}$, respectively (WHO 2004). The content of ions and metals (except $\mathrm{Zn}$ ) in the runoff water of the industrial site is found to be higher than the permissible limits.

\section{Conclusions}

The runoff water is potential non-point sources for polluting water bodies in the country. Nitrate levels in runoff water are found to be several fold higher than the permissible limit of $45 \mathrm{mg} \mathrm{l}^{-1}$ in the industrial site, and expected to be a major culprit for the surface water eutrophication in this region. Similarly, the contamination levels of toxic metals ( $\mathrm{Mn}, \mathrm{Fe}, \mathrm{Cu}, \mathrm{Pb}$ and $\mathrm{Hg}$ ) are found to be higher than permissible limits. The anthropogenic activities (i.e., industrial and coal burning emissions) are major sources of ions and metals in the industrial site. However, vehicular emissions, road and street dusts, sewage overflows, construction debris, atmospheric fallout, etc. are expected major sources of the pollutants in the urban and commercial sites.

Open Access This article is distributed under the terms of the Creative Commons Attribution License which permits any use, distribution, and reproduction in any medium, provided the original author(s) and the source are credited.

\section{References}

Allen P, Mohammad D, Shokouhian SN (2001) Loading estimates of lead, copper, cadmium and zinc in urban runoff from specific sources. Chemosphere 44:997-1009

Ambade B (2012) Physico-chemical assessment of rain, fog and runoff water. Lap-Lambert Academic Publishing, Germany. ISBN: 978-3-659-30271-8

Ambade B (2014) Characterization and source of fog water contaminants in central India. Nat Hazard 70:1535-1552

Ambade B, Ghosh S (2013) Characterization of $\mathrm{PM}_{10}$ in the ambient air during Deepawali festival of Rajnandgaon district, India. Nat Hazard 69:589-598

APHA (2005) Standard methods for the examination of water and wastewater analysis, 21st edn. American Public Health Association, Washington

Avvannavar SM, Shrihari S (2008) Evaluation of water quality index for drinking purposes for river Netravathi Mangalore South India. Environ Monit Assess 143:279-290

Berndtsson JC, Bengtsson L, Jinno K (2009) Runoff water quality from intensive and extensive vegetated roofs. Ecol Eng 35:369-380

Bouwman AF, Van Vuuren DP, Derwent RG, Posch M (2002) Global assessment of acidification and eutrophication of natural ecosystems. Water Air Soil Poll 141:349-382

Burton GA, Pitt RE (2000) Storm water effects handbook. A tool for watershed managers, scientists and engineers. Lewis Publishers, CRC Press, Boca Raton

Chang M, McBroom MW, Beasley R (2004) Roofing as a source of nonpoint water pollution. J Environ Manag 73:307-315
Chattopadhyay S, Rani LA, Sangeetha PV (2005) Water quality variations as linked to land use pattern. A case study in Chalakudy river basin Kerala. Curr Sci 89:2163-2169

Cornelissen G, Pettersen A, Nesse E, Eek E, Helland A, Breedveld GD (2008) The contribution of urban runoff to organic contaminant levels in harbor sediments near two Norwegian cities. Mar Pollut Bull 56:565-573

CPCB (1995) Classification of inland surface waters (CPCB Standards), Water Quality Parivesh. Delhi

Einax JW, Zwanzinger HW, Geiß S (1997) Chemometrics in environmental analysis. Wiley-VCH, Weinheim

Göbel P, Dierkes C, Coldewey WG (2007) Storm water runoff concentration matrix for urban areas. J Contam Hydrol 91:26-42

Ha SR (2003) Estimation of urban runoff and water quality using remote sensing and artificial intelligence. Water Sci Technol 47:319-325

Hao RX, Zhou YW, Liang P, Wang MM, Zhao SQ, Ding YY (2006) Quality and stability analysis for the rainfall water and surface runoff water in southeast region of Beijing municipality. J Environ Sci Health A Tox Hazard Subst Environ Eng 41:1293-1302

Heijerick DG, Janssen CR, Karlèn C, Wallinder IO, Leygraf C (2002) Bioavailability of zinc in runoff water from roofing materials. Chemosphere 47:1073-1080

Hessen DO, Hindar A, Holtan G (1997) The Significance of nitrogen runoff for eutrophication of freshwater and marine recipients. Ambio 26:312-320

Jartun M, Ottesen RT, Steinnes E, Volden T (2008) Runoff of particle bound pollutants from urban impervious surfaces studied by analysis of sediments from stormwater traps. Sci Total Environ 396:147-163

Kaiser HF (1958) The varimax criteria for analytical rotation in factor analysis. Psychometrika 23:187-200

Mangani G, Berloni A, Bellucci F, Tatano F, Maione M (2005) Evaluation of the pollutant content in road runoff first flush waters. Water Air Soil Poll 160:213-228

Mujumdar PP (2008) Implications of climate change for sustainable water resources management in India. Phys Cheme Earth Parts $\mathrm{A} / \mathrm{B} / \mathrm{C}$ 33:354-358

Nabizadeh R, Mahvi A, Mardani G, Yunesian M (2005) Study of heavy metals in urban runoff. Int J Environ Sci Technol 4:325-333

Neal C, Skeffington R, Neal M, Wyatt R, Wickham H, Hill L, Hewitt N (2004) Rainfall and runoff water quality of the Pang and Lambourn tributaries of the River Thames south eastern England. Hydrol Earth Sci Syst 8:601-613

Nouri J, Naghipour KD (2002) Qualitative and quantitative study of heavy metals in runoff of highways of Tehran. Iran $\mathrm{J}$ Public Health $31: 1-8$

Patel KS, Ambade B, Nicolas J, Yubero E (2010) Runoff water pollution in India. Geochimica et Cosmochimica Acta 74:A798A798

Patel KS, Ambade B, Jaiswal NK, Sharma R, Patel RK, Blazhev B, Lautentand M, Bhattacharya P (2012) Arsenic and other heavy metal contamination in central India. In: Understanding the geological and medical interface of arsenic-as 2012 proceedings of the 4th international congress on arsenic in the environment, 22-27 July 2012, 38-39

Polkowska Z, Grynkiewicz M, Zabiegała B, Namieśnik J (2001) Levels of pollutants in runoff water from roads with high traffic intensity in the city of Gdańsk, Poland. Pol J Environ Stud 10:351-363

Polkowska Z, Górecki T, Namieśnik J (2002) Quality of roof runoff waters from an urban region (Gdańsk, Poland). Chemosphere 49:1275-1283

Rao SM, Mamatha P (2004) Water quality in sustainable water management. Curr Sci 87:942-947 
Revitt DM, Hamilton RS, Warren RS (1990) The transport of heavy metals within a small urban catchment. Sci Total Environ 93:359-373

Sargaonkar A (2006) Estimation of land use specific runoff and pollutant concentration for Tapi river basin in India. Environ Monit Assess 117:491-503

Simeonov V, Stratis JA, Samara C, Zachariadis G, Voutsa D, Anthemidis A, Sofoniou M, Kouimtzis T (2003) Assessment of the surface water quality in Northern Greece. Water Res 37:4119-4124

Solaraj G, Dhanakumar S, Murthy KR, Mohanraj R (2010) Water quality in select regions of Cauvery Delta River basin southern India with emphasis on monsoonal variation. Environ Monit Assess 166:435-444

Taebi A, Droste RL (2004) Pollution loads in urban runoff and sanitary wastewater. Sci Total Environ 327:175-184
Tosic M, Bonnell RB, Dutilleul P, Oxenford HA (2009) Runoff water quality, land use and environmental impacts on the Bellairs Fringing Reef, Barbados. Remote sensing and geospatial technologies for coastal ecosystem assessment and management, Chapter 22. Earth Environ Sci 5:521-553

Tsiouris SE, Mamolos AP, Kalburtji KL, Alifrangis D (2002) The quality of runoff water collected from a wheat field margin in Greece. Agric Ecosyst Environ 89:117-125

Venugopal T, Giridharan L, Jayaprakash M, Velmurugan PM (2009) A comprehensive geochemical evaluation of the water quality of river Adyar India. Bull Environ Contam Toxicol 82:211-217

WHO (2004) Guidelines for drinking water quality, 2nd edn. World Health Organization, Geneva

Zafar M, Alappat BJ (2005) Landfill surface runoff and its effect on water quality on river Yamuna. J Environ Sci Health Part A $39: 375-384$ 